\title{
Medical Device Model Family
}

National Cancer Institute

\section{Source}

National Cancer Institute. Medical Device Model Family. NCI Thesaurus. Code C101686.

A grouping of medical devices based upon model name or number. 